\title{
Japanese Manufacturing: Strategy and Practice
}

\author{
P. T. Bolwijn and S. Brinkman
}

\begin{abstract}
A striking characteristic of Japanese factories is the extent of process control: from both the technical and the social viewpoint the labour and production system is controlled down to the very last detail. The characteristics of management and organization which underlie this are closely interwoven with Japanese culture. This explains why the work content, working conditions and working relationships in the factories look so different from those in western cultures. The paper shows why factories in the West cannot and should not copy Japanese factories.
\end{abstract}

\section{Introduction}

On-the-spot obscrvations, and discussions with people both inside and outside factories revealed a number of facts not widely recognized in the West.

This article contains observations, findings and interpretations, with particular regard to companics in the consumer electronics assembly industry; but the conclusions have more general validity.

The main conclusion is best expressed by a Japanese proverb: 'When a crow tries to imitate an eel, it runs the risk of drowning.' In particular, it is not sufficiently realized that the economic system and the social system in Japan are fundamentally different from those in the West. This does not alter the fact that we can learn lessons about what to do, but not how we have to do it.

\section{Design and Layout of the Factories}

In the various companies, factories have to meet a number of requirements which are very recognizable to us. The ways in which these requirements are met are quite different from the methods adopted in the West in a number of essential respects.

The authors are management consultants with Philips International BV, Eindhoven, The Netherlands, currently working in Organization and Efficiency.
From our discussions and observations we arrived at the following conclusions.

\section{Low costs}

An endeavour is made to reduce costs by farming out a great deal of work to subcontractors and/or satellite factories. Sometimes more than half of the work content is farmed out; the factories are therefore specialized. In particular, non-critical processes such as (parts of) $\mathrm{PCB}$ assembly, kit formation and pre-assembly are often subcontracted.

A reduction of costs is also aimed at by taking on young girls or part-time women workers as temporary production personnel.

Cost reduction is also achieved by reducing the number of components and parts.

High quality and delivery reliability of incoming goods High quality and delivery reliability of incoming goods are achieved as a result of long-established relations with subcontractors and the technical support given to them. The same applies to the detailed inspection and reliability examination of components.

\section{Short throughput times}

A short throughput time is achicved partly by ensuring automatic transport with a transport size of one piece and partly by ensuring high process quality.

Great diversity of products and rapid introduction of new types

This is achieved by designing products on a modular basis, by paying great attention to makability (design for assembly) and by having development groups work in parallel (also simultaneously on succecding generations).

Another important point is that use is made of carefully planned starting-up procedures including, among other things, the training of operators 
during pilot production, support from development engineers and over-manning in the startingup phase. Finally, the processing of a wide diversity of products is achieved by making various types on one assembly line (generally speaking, dedicated for each family).

It proves that Sales is the driving force for the current products and Development for the new products. Another striking feature is that there are some integrating functions in the organization which control these management processes. For instance Product Planning links Product Development, Engineering and Sales at plant level, and Corporate Planning links R \& D and Marketing at corporate level.

\section{Growth of production volume}

The plan of the factory is based on growth, which leads to great over-capacity. This is further strengthened by reinvesting the factory's profit in renewal of the production systems.

\section{Motivated employees}

Motivated employees are obtained by 'participation' and indoctrination; quality circles play a major part in this. In selecting new personnel, the ability to be motivated is an important criterion; among other things, job applicants have to pass an entry examination.

\section{Effective management}

Effective production management is promoted by assessing both management and foremen with regard to the morale of their group.

Another method is to have someone from the next higher level attend meetings systematically as a passive observer. One of our contacts called this person a 'watchdog'.

From the above it follows that factories look substantially different from our factories.

In detail they show the following external characteristics:

Mainly final assembly, little subassembly

is Over-capacity in machines and space

is High level of automation of the few subassembly activities and particularly of testing in final assembly

is Automatic transport and components supply, suitable for all kinds of products and including control of the routing in connection with parallel positions

is Non-coupled carriers, ample buffers between individual work stations

is Few process breakdowns, short lead times and, in general, low factory stocks is Batch-flow production, one family per line, high numbers and often great diversity

is Sometimes mixed-model production, then mainly manual work

is Many and long production lines, short cycle timcs, oftcn isolated work stations and work requiring having to stand upright

is Sometimes red signal lamps and indication of allowed walking space

it Assembly mainly done by girls and women

A fairly high number of technicians present on the shop floor

No visible differences in rank or level

is A great deal of information on display screens and notice boards about productivity, quality, costs and suggestions for improvement

Main stages in the process linked (PCB assembly to soldering - testing - final assembly and packaging-palletizing)

Integration of sub-processes here and there.

So, one must be careful in drawing conclusions from the different appearance of the factories.

In particular, account must be taken of the system of the large-scale farming out of certain activities to subcontractors. Account must also be taken of a noteworthy policy relating to personnel and management. A final important factor is that the design and layout of such factories must be seen as innovation projects; the factorics have the character of a parent factory.

\section{Business-economic Aspects}

The method of financing, investing and cost price calculation contains explanatory factors which are still not very widely recognized.

\section{Financing}

The Japanese banking industry came into prominence in the last century. These banks were different from those in the West and their activities were particularly aimed at industrial development.

Frequently a relationship was created between the bank and the business with regard to ownership because the bank was the only lender.

Only a few companies were able to build up shareholders' equity from share capital. It is therefore quite normal to finance a company with only between 5 and 20 per cent shareholders' equity.

Generally speaking, the company pays a low rate of interest on the borrowed capital, but 'contractual' repayment of the loan is not really feasible.

In this way, the bank has a fixed income and this is 
independent of the company's level of profit. All that matters is that it should be able to pay the interest. It is more advantageous to the bank for industry to borrow a lot, rather than to make a high profit.

When the company does make a profit it remains partly in the company and is partly distributed as a bonus and used for investments in expansion (and possibly for the reserves).

These investments are thus aimed more at achieving a growth in volume than at a further increase in profit, also because the system of 'lifelong employment' and salary and promotion based on age make growth essential.

Since it is normal for factories to be 'profit centres', part of the profit flows back directly to the place where it was made.

This is connected with the fact that traditionally in Japan separate trading companies with their own finances handle the commercial activities. Companies with their own commercial departments have taken over this custom, which is strongly supported by the system of cost price calculation.

\section{Cost price calculation}

The method of cost price calculation in Japan is similar to the method known as variable cost calculation. Variable costs are expenses which depend on the size of production, such as the cost of materials and the costs of temporary employees and subcontractors.
Fixed costs are expenses that are independent of the volume of production; such as costs of machines and wage costs of permanent employees. These costs are counted as 'overheads'.

The fixed costs are allocated as a whole and are subsequently covered from the results. The variable costs are included in the cost price per type. It can thus be seen how much is contributed to the earnings by each type.

As already mentioned, this method of cost price calculation supports the functioning of factories as 'profit centres', for part of the earnings have to go back to the factory to cover the fixed costs, and any over-coverage can be reinvested.

The utilization of the available production capacity is promoted by producing all the products that are 'sold' at more than variable costs.

This fosters an approach whereby investments are aimed more at achieving growth in the volume of a total product range than at reducing the cost per type.

It also constitutes a stimulus for product renewal. This method of cost price calculation may therefore partly explain the conduct of the business as we see it.

This can be further illustrated by a simple graph which is used (see Figure 1).

The primary aim is to achieve a growth in volume: in other words, to go as far as possible beyond the break-even point.

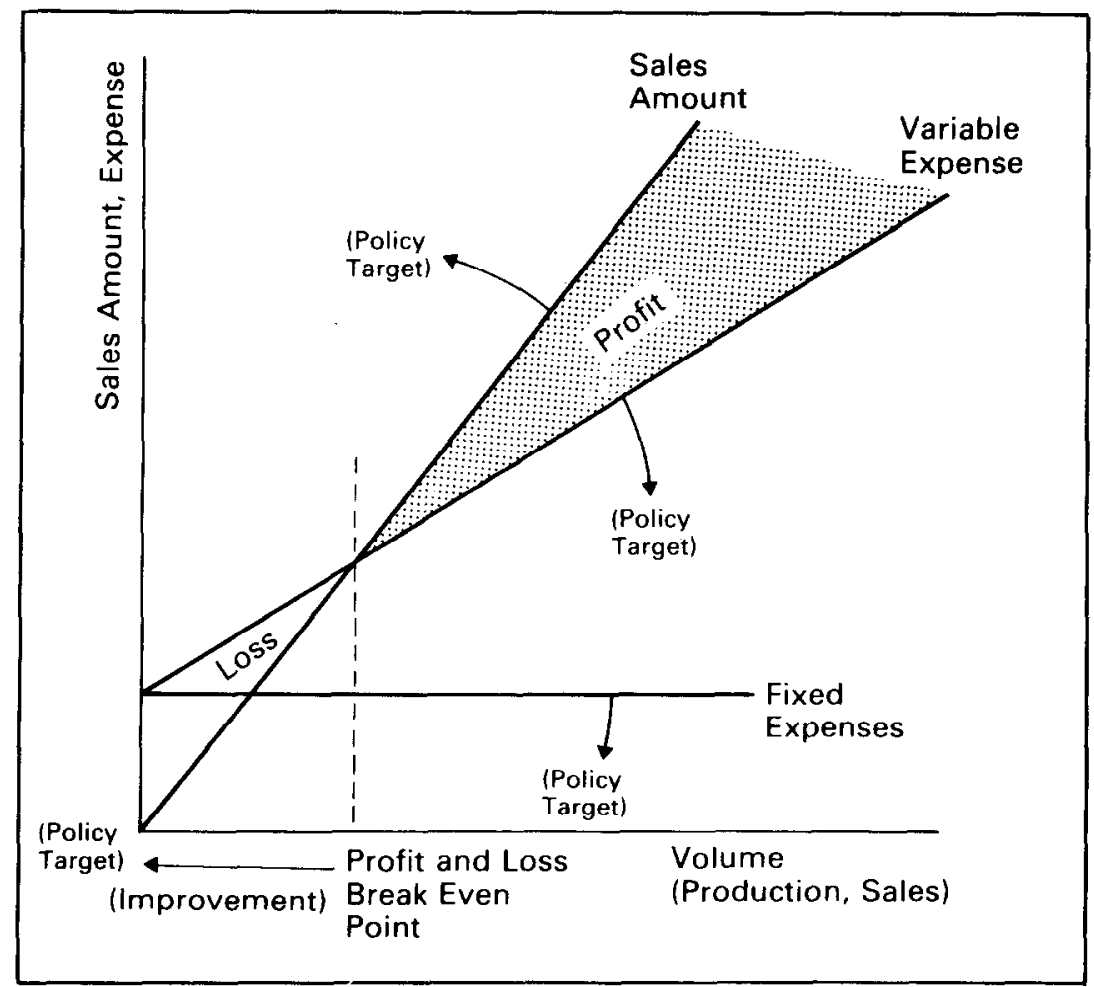

Figure 1. Policy graph 
The next aim is to shift the break-cven point to the left.

It will be clear that investments in mechanizations/ automation must be seen in this light.

\section{Automation/mechanization}

When selecting profitable projects, one uses an overview of the total production process in terms of sub-processes and the related investment for automation per sub-process or cluster of sub-processes.

In answer to questions about the reasons for automation/mechanization we were given one or more of the following answers:

is better quality

is few variable costs

is greater production volume

is to offset a shortage of production personnel

is to eliminate monotonous work.

We cannot avoid the impression there is also thought to be no better way of spending the profit earned. This is understandable, for the factories do not have so many alternatives open to them.

Management in fact, has a passion for advanced technology, the point being that this serves higher purposes: "Technology for mankind and for upgrading of the culture and welfare of all people around the world.' A part from all that, for the time being unmanned assembly factories are not regarded as feasible.

\section{How are the Market Requirements Met?}

This section describes the external characteristics of Japanese factorics from the angles of efficiency, quality and flexibility. These are the characteristics that can be ascertained as a result of observations and discussions during the visits. We shall not repeat what has already been said by many others about this with regard to individual aspects. We shall, however, endeavour to sketch a total picture in which, above all, the interrelationship between the individual aspects becomes visible.

\section{Efficiency}

Some striking factors can be noted which result in large Japanese production companies having a relative advantage in the cost field.

\section{Materials}

The cost of materials is lower because of the use of small subcontractors who, in their turn, also make use of subcontractors, small suppliers and home workers. In small companies wages are lower (3050 per cent) and working days and weeks are longer (up to many tens of per cents). The cost of materials is also lower because the stock of parts and subassemblies is smaller for, financially speaking, this stock is held by subcontractors and suppliers; in physical terms, the stock is somctimes actually kcpt in the main company.

The main company also has further advantage in that payment periods are long (sometimes subcontractors are not even paid until the final products have been sold).

\section{Investments}

The level of mechanization and automation varies widely. High levels of automation occur, in which respect it must be remembered that the labourintensive tasks are subcontracted.

As a result of all this, the amount of capital tied up in the assembly industry is often less than in the West. Machines are frequently leased to subcontractors.

Investment costs can be lower than those in western countries because of the low interest rate although this can be more than cancelled out by a relatively large volume of borrowed capital.

Banks have enough money, for the Japanese are great savers. This is because bringing up children, educating them, providing a dowry, housing and providing for old age are very expensive.

For certain investments, banks are also prepared to provide money at an extra low interest rate if these relate to the technologies selected by the MITI.

\section{Personnel}

Personnel costs can be lower than those in western countrics, or yield higher returns because of a number of factors. All the companies visited make large-scale use of women and part-timers who have a temporary contract, are paid lower wages (half to twothirds) and are never promoted. In contrast to other branches of industry no seasonal workers are used in the electronics industry.

In the case of younger people (18-24 years) 70 per cent of the direct employees consist of girls; in one of the companics visited the figure was as high as 90 per cent. Most girls remain in employment for only a short time until they marry.

Only the permanent male workers in large companies have life-long employment $(20-30$ per cent of all workers). Their wage levels are no (longer) lower than those in many western countries. Companies pay fewer social charges (but more for housing accommodation, sport and various other facilities such as cookery lessons, sewing lessons, and the use of the library, all of which were proudly shown to us in one of the companies). 
Workers receive lower sickness benefit. The retirement age is generally lower than in the West (in 40 per cent of the companies 55 years, in the electronics industry varying from 55 to 60 years). Retired people are often financially compelled to accept temporary work. Managers who do not make the grade are offered a redundancy arrangement at the age of about 45 years.

Educational levels are relatively high, the minimum level being secondary school for 95 per cent of the present generation. As a result of the system of onthe-job training and job rotation there are a relatively large number of technical graduates in lower indircet functions. The starting salaries for graduates are low for a long period in the company. For the rest, in principle it is only graduates who can aspire to the ranks of management.

All the employees in the companies visited receive a variable bonus twice a year (up to many tens of per cents of the annual salary) depending on the company's results.

The existence of loyal trade unions in each company (which is sometimes actively promoted by companies) can also limit wage and salary costs.

Working hours are longer than those in the West and there are fewer holidays. Seventy-five per cent of the employees have less than 2 weeks; in the clectronics industry holidays range from 12 to 20 days, depending on the length of service. There are 12 national public holidays. As a result of company and/or social pressure, the holiday allowance is often not taken up in full. In one of the companies visited, employees were forced to take their holiday in quiet periods. Half of the companies in Japan have a 5-day working week once per month. Many work continuously on a $5 \frac{1}{2}$ - to 6 -day week. All in all, 15 per cent more hours are worked annually in large companies than in Western Furope. There is a great deal of compulsory overtime; between 10 and 15 per cent overtime is very common (sometimes unpaid, but generally about 30 per cent is added to the wage).

Part-time workers do not do overtime but they do work an (almost) full day (in three of the companies visited $6,6 \frac{3}{4}$ and 8 hours per day, respectively).

One company visited put in 24 hours' operating time with two shifts by means of overtime in a small capital-intensive department.

A maximum of 30 hours' overtime per month is legally permitted. We were told that illegal overtime is not unusual.

In some of the companies visited we were told that meetings of quality circles and management :neetings are held outside working hours.

\section{Conclusion}

From the above it can be seen that there are quite a few factors which result in large Japanese production companies having a relevant advantage in the field of costs.

Many of these factors can be attributed to the way in which production is allocated on the one hand and to the dual economy of Japan on the other hand.

Production allocation is based on a division of tasks between the parent company, satellite factories and subcontractors, resulting in specialized factories. The resulting cost advantages are further intensified by the dual economy. In this dual economy there are great differences in wages, working hours, working conditions and social security between large and small companies, between various sectors of society and between groups of employees. That duality, incidentally, is a topic of discussion in Japan on a small but increasingly larger scale. The position of the trade unions, which are demanding a wage increase, shorter working hours and technology agreements, is interesting in this respect.

\section{Quality}

The approach to quality, which is known as Total Quality Control (TQC), has the following characteristics:

25 It is recognized as a strategic issue, with commitment on the part of top management, and the quality department being positioned high in the organization.

is It is aimed at step-by-step improvement of the company as a whole: products, production processes, working environment, organization, management, etc.

is It makes use of concrete plans for all levels, everyone being involved in these and trained in methods and techniques.

it It is based on the continuous and systematic collection, analysis and feedback of processinformation, as well as information on competitors and the market.

it is supported, both in the company and nationally, by promotional activities.

Most of these characteristics can in fact be observed during visits.

This TQC approach leads to a number of characteristics of production organizations which are confirmed by asking about them, such as:

t) A high level of process control (few defects and rejects, few stocks, no over-loaded machines, what is planned is made-no more and no less)

is Makable product designs and workable produc- 
tion methods (designers and engineers work together and know the production process)

is High quality of incoming goods (100 per cent incoming inspection or co-makership with sanctions and technical support)

is Employees oriented towards quality (compulsory attention to improvements with a strong element of competition)

is Simple inspection and control systems (everyday matters are settled on the shop floor).

Quality is therefore more than product quality and concerns the total conduct of the business, as can be seen from the approach outlined above.

That is also clear from the objectives of quality circles. In one of the companies visited, for example, the quality circles have five aims: to improve quality, increase productivity, strengthen morale, reduce costs and maintain safety.

Within that context, great value is attached to 'education'. The intention of this is to point all the employees in the same direction and, if necessary, to change the mind of the people.

One regularly hears statements such as 'we have to change the mentality' and 'we will influence the mind of the employee'.

Speaking in a wider context, one of our contacts expressed his concern about the dangerous aspects of such forms of motivation, referring to the history of Japan.

\section{Conclusion}

Reviewing the quality approach in the companies visited it may be said that there is one factor of major importance, namely the fact that top management has selected quality as a competitive weapon, which is continuously, systematically and in detail developed and made operational for all policy areas.

\section{Flexibility}

A distinction is made as regards the extent to which and the way in which flexibility is aimed at, as well as between types of flexibility.

\section{Volume flexibility}

Fluctuations are cushioned by a number of measures which are taken either individually or in combination. The high level of process control helps in this respect. In all the companies visited, the employees are very frequently used as a capacity buffer, based on overtime working or transfers. Many of the employees can be put to work at evcry position on the asscmbly line and on other lines (multi-skill).

The production volume can also be changed relatively easily because there is planned overcapacity. The volume is altered by changing the pace and, if necessary, the number of people used.

Suppliers, subcontractors and satellite factories are compelled to react accordingly.

Long-term or extensive changes (including seasonal fluctuations) are coped with by engaging part-time employees and by farming out a varying amount of work to subcontractors. Sometimes satellite factories are even set up for this purpose. Workers can also be transferred within the group of companies to which the enterprise concerned generally belongs.

\section{Mix flexibility}

As a result of the high volumes, the mix flexibility generally need not be so great in order to be able to deliver a wide diversity of products.

Mix flexibility is aimed at by using a combination of many 'dedicated' assembly lines for each - often largefamily and 'mixed model' production within families.

We mainly encountered batch-flow production. The dedicated lines are used for the relatively large series. The necessary volume flexibility is obtained as described above. The employees, too, are 'dedicated', multi-skilled and in principle work per line. The impression exists that satellite factories are also used for the production of relatively small series.

In batch-flow production various models are made in batches within a family, all mixed up on the same line. As far as possible the aim is to achieve batches of at least one day's production.

Furthermore, making exactly the required mix each day partly reduces the need for mix flexibility and partly increases the possibility for doing this. Mixed-model production is achieved by using a range of measures:

is modular product designs; the emphasis is on derived models closely related to the standard model

is standard components and parts

is universal test equipment with short setting-up times

is standard product carriers with a transport batch $=1$

is buffers between the work stations

is multi-skilled employees.

In addition, orders for small batches can be placed with subcontractors who handle the pre-assembly and kit formation.

A precondition for achieving good mix flexibility is process control in the widest sense of the term. 
Start-up flexibility

Great efforts are made to achieve high flexibility in start-up. The development process is gone through rapidly. We were told that development engineers and management often sit together in one room, deal with one project simultaneously, plan from day to day and do a great deal of overtime.

Wherever possible, development is done in parallel. In the case of larger product innovations parallel groups often work on the same project in competition with each other. At a certain moment, the best type or model is further developed on a joint basis.

A normal approach is for the parent factory to concentrate mainly on making new products and trying out new production methods in a pilot-type situation. Familiar, non-critical technologies are then subcontracted, if necessary, for example to satellite factories. This leads to the activities being focused on starting up new products and technologies.

\section{Conclusion}

A great many factors appear to be decisive for the flexibility of Japanese manufacturing. In addition to the dual economy (subcontractors, part-timers) and the well-known design rules for products and machines, the extent of process control obviously also plays a part. From both the technical and social viewpoints the labour and production system is controlled down to the very last detail. The characteristics of management and organization on which this is founded are dealt with in the next section.

\section{Socio-technical Choices}

In this section we shall look at the character that underlies the external features. That character dctcrmines the decper-seated causes of the external form of Japanese manufacturing. It is necessary to know this character in order to understand the Japanese approach to manufacturing or to see what we can learn from it. For that reason, the western and Japanese approaches are placed side by side in mirror fashion by way of comparison.

\section{Historical Roots}

Many characteristics of Japanese society can be explained as the result of centuries of historical development of country and people, as shown in Table 1 (a one-to-one relationship is not suggested in every case).

Separate mention must be made of the strong urge for survival which is cultivated by the government and industry, and to which everything is subordi-
Table 1. Historical roots of Japanese society

\begin{tabular}{ll}
\hline Characteristics & Sources \\
\hline $\begin{array}{l}\text { Strong sense of identity } \\
\text { Strong sense of } \\
\text { exclusiveness } \\
\text { Homogeneous population }\end{array}$ & $\begin{array}{l}\text { Island } \\
\text { Centuries of isolation }\end{array}$ \\
$\begin{array}{l}\text { Eye for detail, precision } \\
\text { and determination }\end{array}$ & Complicated picture writing \\
$\begin{array}{l}\text { Much oral and informal } \\
\text { transfer of information }\end{array}$ & \\
$\begin{array}{l}\text { Mutual dependence } \\
\text { Striving for harmony } \\
\text { Discipline and conformity }\end{array}$ & $\begin{array}{l}\text { Wittle habitable space and } \\
\text { high population density }\end{array}$ \\
$\begin{array}{l}\text { Urge for survival } \\
\text { Fear of the unexpected }\end{array}$ & Eo energy and raw materials \\
of their own
\end{tabular}

nated. This, too, is a phenomenon with a long history, although its form has changed:

isolation to prevent colonial domination (16411854)

is expansion using military power (1854-1945)

is growth through economic power (1945-present).

In the period of economic growth the motto is 'import to survive, export to import'.

It is striking to note how frequently 'survival' is put forward as an argument in discussions. When we asked why the Japanese work so hard, the answer was: 'We have to, for the cost of living is so high!' and indeed, the figures show that salary increases over many years were only just able to keep pace with inflation. In Japan, too, people sometimes ask where all that work is getting them. People are told that they must be patient, for better times are coming.

Religion was, and still is, a lubricant that must not be underestimated in the process of industrialization and economic growth. It should be noted that companies often justify their role with religious-sounding formulas which make it clear that they are contributing to the glory of mankind. It would seem that industrial enterprises in Japan have a mission in the world. 


\section{Cultural Characteristics}

From these historical roots a culture emerges that is quite different from that of the industrialized West, as shown in Table 2.

It is striking to note that the strong hierarchical structure goes hand in hand with direct personal relationships. The reciprocal nature of this means that care, love, justice, etc., from those in higher positions (husband, parents, older people, the ruler, management) is responded to with loyalty, respect, obedience, etc. by those in lower positions (wife, children, younger people, subject, employee). Everyone knows his place and this is constantly confirmed because the use of language depends on one's role and position.

Upbringing and education are reinforcing mechanisms. A tremendous urge to achieve predominates in education right from the start, aimed at getting into better and higher schools and hence at acquiring better and higher positions.

Table 2. A comparison of western and Japanese culture

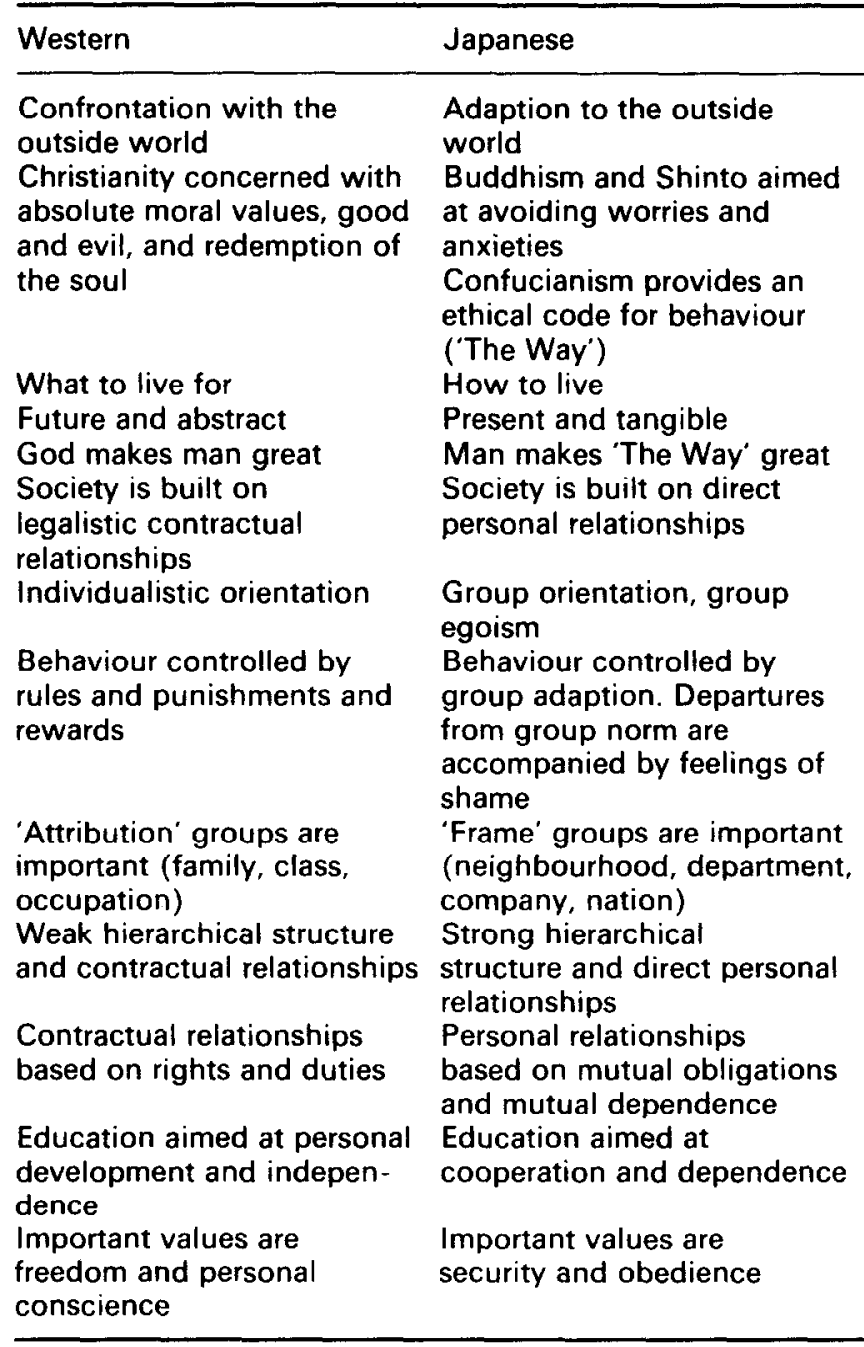

All in all, it is clear that employees are 'patient' and 'diligent' as is often told.

As a result of the 'shame' culture they will make every endeavour to do their duty and hence make their prescribed contribution to the group task, as we werc assured in onc of the companics. Incidentally, the fact that the reciprocal nature of vertical relationships is not entirely self-evident is clear from the comment that loyalty of the employees is bought by management.

\section{Management and Organization}

The characteristics of management and organization bear the traces of the culture in which the large company is located, as shown in Table 3.

It will be clear that in the past decade the major companies have tied in shrewdly and strongly with the culture.

Teamwork, loyalty and paternalism occupy a striking position.

The fact that both employees and management feel morally and materially bound to each other and to the company is further strengthened by the system of appraisal and rewards that forces people, from high to low, to co-operate and aim at achieving results. This also explains why in the factories visited the work content, working conditions and working relationships may look essentially different from those in the West.

\section{Conclusions}

Large production companies aim at cost reductions and increased flexibility mainly by utilizing specialized factories and by making use of the dual economy (subcontractors, temporary employees). In that dual economy great differences exist between large and small companies, between various sectors of society and between groups of employees with regard to wages, working hours, working conditions and social security.

A striking characteristic of the production companies, partly resulting from the instrumental approach to quality, is the extent of process control: from both the technical and the social viewpoint the labour and production system is controlled down to the very last detail. The characteristics of management and organization which underlie this are closely interwoven with Japanese culture. Teamwork, loyalty and paternalism occupy a striking position. The system of appraisal and rewards compels everyone, from high to low, to co-operate and aim at results. 
Table 3. Typical characteristics of management and organization, showing the fundamental differences

\begin{tabular}{|c|c|}
\hline West & Japan \\
\hline \multicolumn{2}{|c|}{ Personnel } \\
\hline $\begin{array}{l}\text { Strict separation between } \\
\text { company and employee } \\
\text { Has a say and is } \\
\text { independent }\end{array}$ & $\begin{array}{l}\text { Company life and private } \\
\text { life are two things in one } \\
\text { Devoted and dependent }\end{array}$ \\
\hline $\begin{array}{l}\text { Company training courses } \\
\text { without examinations }\end{array}$ & $\begin{array}{l}\text { Company training courses } \\
\text { with examinations }\end{array}$ \\
\hline Little job rotation & Great deal of job rotation \\
\hline $\begin{array}{l}\text { Passive indirect } \\
\text { participation } \\
\text { Competition between }\end{array}$ & $\begin{array}{l}\text { Active direct participation } \\
\text { and indoctrination }\end{array}$ \\
\hline $\begin{array}{l}\text { Competition between } \\
\text { individuals }\end{array}$ & Competition between groups \\
\hline
\end{tabular}

This explains why the work content, working conditions and working relationships in the factories look so different from those in the West.

Some characteristics which promote quality and flexibility and are less closely interwoven with the culture are:

the specialized nature of the factories, and the design of 'factories within a factory'

is product design rules (e.g. design for assembly)

over-capacity, both in space and machines

automated transport, both of products and of components and subassemblies, and the drive for automated testing

is integration of functions.

In the innovation path, product and process development and production preparation are integrated in one department.

In the production field, operation and improvement are integrated in the production workers.

In the management field, the operational and controlling functions are admittedly separate as regards the persons responsible for them, but at meetings the exercise of these management functions is 'integrated', because both persons are present.

Japan's dual economy and coercive social system cannot and should not be copied by the West.

Some aspects which may serve as a basis for lessons directed towards the improvement of western industry are:

is The important position occupied by production in the company, and by industry in society. Upgrading of both is essential.

is The realization of the mutual dependence of management and workers in the company, and of industry, government and workers' unions in socicty.

More recognition of common interests is necessary.

is The gearing to each other of technology and labour, and how they fit into the culture as a whole. What matters is the integration of technological and social innovation in the company, and of social and economic renewal in society.

it The effective method of cooperation.

Cooperative leadership is urgently needed.

This approach* can counter a tendency toward the 'Japanization' of western society.

*This subject is dealt with in detail in P. T. Bolwijn, T. Kumpe et al., Flexible Manufacturing: Integrating Technologicaland Sociallinnovation, Elsevier, Amsterdam (1986). 


\section{Bibliography}

Andrew Weiss, Simple truths of Japanese manufacturing, Harvard Business Review (July-August 1984), p. 119.

B. Bruce-Briggs, The dangerous folly called Theory $Z$, Fortune (17 May, 1982), p. 41.

Peter F. Drucker, Economic realities and enterprise strategy, in Modern Japanese Organization and Decision-Making, ed. Ezra $\mathrm{F}$. Vogel (Tokyo, 1983), p. 228.

Gene Gregory, Why Japan's engineers lead, Management Today (May 1984), p. 50

Robert $H$. Hayes, Why Japanese factories work, The McKinsey Quarterly (Autumn 1982), p. 32.

Satoshi Kamata, Japan in the Passing Lane (New York, 1982).

George Mikes, The Land of the Rising Yen (London, 1970).

Chie Nakana, Human Relations in Japan (Tokyo, 1972).

George S. Odiorne, The trouble with Japanese management systems, Business Horizons (July-August. 1984) p. 17.

Kenichi Ohmae, Myths and realities of Japanese corporations, The McKinsey Quarterly (Summer 1981), p. 2.
Kenichi Ohmae, Japan: from stereotypes to specifics, The McKinsey Quarterly (Spring 1982), p. 2.

Terutomo Ozawa, Japanese chic, Across the Board (October, 1982), p. 6.

Thomas P. Rohlen, The company work group, in Modern Japanese Organization and Decision-Making, ed. Ezra F. Vogel (Tokyo, 1983), p. 185.

Richard J. Schonberger, Japanese Manufacturing Techniques (New York, 1982).

S. Prakash Sethi, Nobuaki Namiki and Carl L. Swanson, The decline of the Japanese system of management, California Management Review 26 (Summer 1984), p. 35.

Merlin Stone, Competing with Japan-the rules of the game, Long Range Planning 17 (1984) p. 33.

George A. de Vos, Apprenticeship and paternalism, in Modern Japanese Organization and Decision-Making, ed. Ezra F. Vogel (Tokyo, 1983), p. 210.

Jon Woronoff, The Japan Syndrome (Tokyo, 1985). 